\title{
Analisis Kinerja UMKM Mitra Binaan PT. Chevron Pacific Indonesia Dengan Motivasi Usaha Sebagai Variabel Moderasi
}

\author{
Harry Kurniawan' ${ }^{1}$ Machasin $^{2}{\text { Sakdanur } \text { Nas }^{3}}^{3}$ \\ 1) Mahasiswa Program Pascasarjana Universitas Riau, Pekanbaru, Indonesia \\ ${ }^{2,3)}$ Dosen Program Pascasarjana Universitas Riau, Pekanbaru, Indonesia
}

\begin{abstract}
ABSTRAK : Penelitian ini dilakukan pada UMKM Binaan PT Chevron Pacific Indonesia di Riau. Tujuannya adalah untuk mengetahui efek langsung dari pengalaman kerja, keterampilan dan Networking terhadap kinerja UMKM dengan motivasi usaha sebagai variabel Moderasi. Penelitian mengambil Sampel sebanyak 70 UMKM. Variabel yang digunakan adalah pengalaman, keterampilan, Networking, Kinerja UMKM dan Motivasi Usaha sebagai Moderasi. Data dianalisis dengan menggunakan analisis SEM (Structural Equation Modelling).

Hasil penelitian menunjukan bahwa usia 40-49 tahun merupakan usia yang memiliki kinerja yang sangat baik dengan nilai 4,20. Dan jenis kelamin perempuan memiliki kinerja yang baik dengan nilai 4,10. Kemudian hasil penelitian menunjukkan bahwa terdapat pengaruh pengalaman kerja, keterampilan dan Networking terhadap kinerja UMKM. sedangkan pengalaman kerja dan keterampilan yang dimoderasi dengan motivasi usaha tidak berpengaruh terhadap kinerja UMKM. Sedangkan networking yang dimoderasi oleh motivasi usaha berpengaruh terhadap kinerja UMKM.
\end{abstract}

Kata Kunci : pengalaman kerja, keterampilan, networking, motivasi dan kinerja UMKM

ABSTRACT : The study was conducted at PT Chevron Pacific Indonesia fostered UMKM in Riau. The aim is to find out the direct effect of work experience, skills and networking on the performance of UMKM with business motivation as a moderation variable. The study took a sample of 70 UMKM. The variables used are experience, skills, Networking, UMKM Performance and Business Motivation as Moderation. Data were analyzed using SEM (Structural Equation Modeling).

The results showed that the age of 40-49 years is an age that has a very good income with a value of 4.20. And female sex has a good performance with a value of 4.10. Then the results of the study indicate that there is work participation, skills and networks for the performance of UMKMs. Whereas work experience and skills that are moderated with business motivation do not support UMKM performance. While the network is moderated by motivation to try to the performance of $U M K M$ s

Keywords: work experience, skills, networking, UMKM performance and business motivation

Email Address : h.kurniawan.st@gmail.com 


\section{PENDAHULUAN}

UMKM di negara Indonesia keberadaan nya dianggap penting. Dalam pelaksanaan nya UMKM disusun regulasi tersendiri yaitu UU No 20 Tahun 2008 yang menjelaskan menyenai peraturanperaturan UMKM. Kriteria UMKM dijelaskan dalam UU tersebut bahwa dunia usaha dibedakan menjadi usaha mikro, usaha kecil, usaha menengah dan usaha besar. Segmentasi usaha mikro, kecil dan menengah sering digolongkan secara khusus karena mewakili segmen rakyat kecildengan sebutan rakyat mikro kecil dan menengah (UMKM). Berdasarkan UU tersebut, UMKM adalah usaha produktif yang memenuhi kriteria usaha dengan batasan tertentu kekayaan bersih dan hasil penjualan tahunan. Keberadaan UMKM ini tidak boleh dipandang sebelah mata. UMKM merupakan salah satu sektor strategis dalam perekonomian nasional. Tujuan UMKM yaitu menumbuhkan dan mengembangkan usaha nya dalam rangka membangun perekonomian nasional berdasarkan demokrasi ekonomi yang berkeadilan.

Hubungan perusahaan dan masyarakat yang bermukim di sekitarnya merupakan dua komponen yang saling mempengaruhi.Aktivitas perusahaan tidak dapat dipungkiri memiliki dampak terhadap masyarakat sekitarnya. Dampak tersebut dapat berupa dampak positif ( seperti penciptaan lapangan kerja dan peningkatan ekonomi), maupun dampak negatif ( seperti penurunan kualitas lingkungan dan kesehatan masyarakat ). Hubungan masyarakat atau public relations merupakan suatu usaha yang dilakukan dan direncanakan secara berkesinambungan untuk menciptakan saling pengertian antara sebuah lembaga atau instansi dengan masyarakat. Pada hakikatnya kegiatan - kegiatan public relations bertujuan untuk membina hubungan baik public dalam maupun publik luar perusahaan.

Berdasarkan latar belakang diatas maka peneliti mencoba melakukan penelitian dengan objek yang berbeda yaitu pada UMKM binaan PT Chevron Pacific Indonesia. Dengan judul "Analisis kinerja UMKM Mitra Binaan PT Chevron Pacific Indonesia Dengan Motivasi Sebagai Variabel Moderasi”

Hasibuan (2010) menyatakan bahwa kinerja adalah suatu hasil kerja yang dicapai seseorang atau organisasi dalam melaksanakan tugas-tugas yang dibebankan kepadanya yang didasarkan atas kecakapan, pengalaman dan kesungguhan serta waktu. Sedangkan menurut Veithzal Rivai (2005) dalam kinerja adalah hasil atau tingkat keberhasilan seseorang secara keseluruhan selama periode tertentu di dalam melaksanakan tugas dibandingkan dengan kemungkinan, seperti hasil kerja, target, sasaran atau kriteria yang telah ditentukan terlebih dahulu dan telah disepakati bersama. Pengertian lain disampaikan oleh Helfert (dalam indarti, 2004) bahwa kinerja perusahaan adalah suatu tampilan keadaan secara utuh atas perusahaan selama periode waktu tertentu, merupakan hasil atau prestasi yang dipengaruhi oleh kegiatan operasional perusahaan dalam memanfaatkan sumber daya-sumber daya yang dimiliki.

Kinerja adalah merujuk pada pencapaian atau prestasi dari perusahaan dalam waktu tertentu. Variabel dalam penelitian ini dikembangkan dari kinerja yang telah diteliti oleh Minuzu (2010). Adapun indikator yang digunakan untuk mengukur kinerja UMKM adalah:

1. Pertumbuhan penjualan

2. Pertumbuhan modal

3. Penambahan tenaga kerja setiap tahun

4. Pertumbuhan pasar dan pemasaran 
5. Pertumbuhan keuntungan / laba usaha

Beberapa pendapat mengenai motivasi menurut para ahli, Winardi mengemukakan (2016:6) bahwa motivasi merupakan suatu kekuatan potensial yang ada di dalam diri seorang manusia, yang dapat dikembangkannya sendiri atau dikembangkan oleh sejumlah kekuatan luar yang pada intinya berkisar sekitar imbalan moneter dan imbalan non moneter, yang dapat mempengaruhi hasil kinerjanya secara positif atau negatif.

Dimensi dan Indikator motivasi dalam penelitian ini mengacu pada Veithzal dan Basri (2016:837) adalah sebagai berikut :

1. Dimensi kebutuhan akan prestasi (Need Achievment) yang terdiri dari empat indikator yaitu :
a. Kebutuhan mengembangkan kreativitas
b. Kebutuhan untuk meningkatkan kemampuan
c. Kebutuhan mencapai prestasi tertinggi
d. Kebutuhan untuk bekerja secara efektif dan efisien

2. Dimensi kebutuhan akan afiliasi (Need Affiliation) yang terdiri dari tiga indikator yaitu :

a. Kebutuhan untuk diterima

b. Kebutuhan untuk menjalin hubungan baik antar karyawan

c. Kebutuhan untuk ikut serta dan bekerja sama

3. Dimensi kebutuhan akan kekuasaan (Need for Power) terdiri dari tiga indikator yaitu:
a. Kebutuhan untuk memberikan pengaruh
b. Kebutuhan mengembangkan kekuasaan dan tanggung jawab
c. Kebutuhan untuk memimpin dan bersain

$\begin{array}{lrr}\begin{array}{c}\text { Pengalaman } \\ \text { pembentukan }\end{array} & \begin{array}{r}\text { merupakan } \\ \text { pengetahuan }\end{array} & \text { atau }\end{array}$ keterampilan tentang metode suatu pekerjaan karena keterlibatan karyawan tersebut dalam pelaksanaan tugas pekerjaan. Pengalaman kerja ialah ukuran tentang lama waktu atau masa kerja yang telah ditempuh seseorang untuk dapat memahami tugas-tugas suatu pekerjaan dan telah melaksanakan pekerjaanya dengan baik. Dengan demikian orang yang berpengalaman mempunyai peluang yang lebih besar untuk mengerjakan tugastugas perusahaan dengan baik dibandingkan dengan orang yang belum berpengalaman.

Menurut Edy mendefinisikan pengalaman kerja sebagai berikut: "Pengalaman kerja adalah suatu dasar/acuan seorang karyawan dapat menempatkan diri secara tepat kondisi, berani mengambil resiko, mampu menghadapi tantangan dengan penuh tanggung jawab serta mampu berkomunikasi dengan baik terhadap berbagai pihak untuk tetap menjaga produktivitas, kinerja dan menghasilkan individu yang kompeten dalam bidangnya.Pengalaman kerja merupakan lamanya waktu yang dijalani seorang karyawan ataupun pegawai dalam menjalankan banyaknya penugasan maupun jenis-jenis pekerjaan yang pernah ditangani. Menurut Foster Bill (2001:43) Ada beberapa hal juga untuk menentukan berpengalaman tidaknya seorang karyawan yang sekaligus sebagai indikator pengalaman kerja yaitu:

1. Lama waktu/ masa kerja. Ukuran tentang lama waktu atau masa kerja yang telah ditempuh seseorang dapat memahami tugas-tugas suatu pekerjaan dan telah melaksanakan dengan baik.

2. Tingkat pengetahuan dan keterampilan yang dimiliki. Pengetahuan merujuk pada konsep, prinsip, prosedur, kebijakan atau 
informasi lain yang dibutuhkan oleh karyawan. Pengetahuan juga mencakup kemampuan untuk memahami dan menerapkan informasi pada tanggung jawab pekerjaan. Sedangkan keterampilan merujuk pada kemampuan fisik yang dibutuhkan untuk mencapai atau menjalankan suatu tugas atau pekerjaan.

3. Penguasaan terhadap pekerjaan Tingkat penguasaan seseorang dalam pelaksanaan aspek-aspek teknik peralatan dan teknik pekerjaan

4. Penguasaan terhadap peralatan kerja. Tingkat penguasaan seseorang dalam pelaksanaan aspek-aspek teknik peralatan dan teknik pekerjaan.

Menurut Spencer yang dikutip oleh Srinivas R. Kandula (2013:6), Keterampilan dapat dibagi menjadi dua kategori yaitu keterampilan dasar (Threshold Competency) dan keterampilan pembeda (Differentiating Competency). Kedua kategori tersebut diklasifikasikan menjadi dimensi-dimensi dan indikator sebagai berikut :

1. Indikator pada dimensi pengetahuan, meliputi :
a. Pengetahuan Faktual
b. Pengetahuan Konseptual
c. Pengetahuan Prosedural

2. Indikator pada dimensi kompetensi, meliputi :
a. kompetensi Administratif
b. kompetensi Manajerial
c. kompetensi Teknis
d. kompetensi Sosial

3. Indikator pada dimensi motif, meliputi :
a. Dorongan Ekonomi
b. Dorongan Sosial
c. Dorongan Psikologis

4. Indikator pada dimensi sifat, meliputi : Sikap

5. Indikator pada dimensi citra diri, melputi : a. Kepercayaan Diri

b. Nilai-nilai Pribadi Keterampilan merupakan karakteristik yang mendasar pada setiap individu yang dihubungkan dengan kriteria terhadap kinerja yang unggul atau efektif dalam sebuah pekerjaan atau situasi.

Menurut Suryana dan Bayu (2013:176), seorang wirausaha tidak dapat hidup sendiri dalam menjalankan usahanya, namun ada keterkaitan dengan pihak luar baik sebagai pemasok, pelanggan, maupun pedagang perantara. Oleh karena itu, diperlukan suatu jaringan usaha agar usaha yang kita jalankan berkelanjutan. Untuk bertahan dalam dunia yang penuh persaingan, penting sekali untuk mengembangkan sebuah entrepreneurial dan jaringan sosial dari informasi dan lainya. Jaringan usaha memiliki peran penting dalam mendukung eksportir dan mengembangkan kontak global dan internasional dan hubungan perdagangan, menjadikan dunia sebagai negeri global (Carsrud dan Brannback, 2007). Menurut Flynn (2010:3) jaringan adalah seni yang sangat diperlukan dalam membangun relasi timbal-balik jangka panjang dengan orang yang tepat.

Menurut Taormina dan Kin Lao (2007) untuk mencapai tujuan personal maupun perusahaan digunakan:

- Building Personal Relationship

- Having a Favorable Attitude

\section{Metodologi penelitian}

Jenis Penelitian

Jenis penelitian yang digunakan dalam penelitian ini adalah metode kuantitatif dengan menanyakan hubungan kasual (sebab-akibat). Penelitian ini dilakukan dengan pendekatan penelitian kuantitatif yaitu peneliti menggunakan kuesioner, observasi, dan wawancara dalam melakukan teknik pengumpulan data. 


\section{Populasi dan Sampel}

populasi dalam penelitian ini adalah seluruh UMKM binaan PT Chevron Pacific Indonesia Provinsi Riau pada Tahun 2019 berjumlah sebanyak 214 UMKM. Dari perhitungan menggunakan rumus slovin, maka dapat diperoleh jumlah sampel dalam penelitian ini adalah 70 responden.

\section{Analisis Data}

Penelitian ini menggunakan metode analisis data dengan menggunakan software SmartPLS versi 3.2.7.

\section{Hasil dan Pembahasan}

\section{Uji Validitas}

Validitas atau kesahihan suatu instrumen adalah ukuran seberapa tepat instrumen itu mampu menghasilkan data sesuai dengan ukuran yang sesungguhnya yang ingin diukur. Untuk pengujian validitas dalam penelitian ini menggunakan construct validity yang terbagi menjadi dua yaitu konvergen dan diskriminan (Ghozali \& Latan, 2014:91).

\section{Validitas Convergent}

Validitas konvergen (convergent) bertujuan untuk menguji korelasi antar item/indikator untuk mengukur konstruk. Dengan kata lain validitas konvergen ingin mengkonfirmasi pengukuran konstruk (Ghozali \& Latan, 2014:91).

Tabel 1: Uji Validitas Covergent Variabel Penelitian

\begin{tabular}{cccc}
\hline Variabel & Indikator & Load & Ket \\
\hline \multirow{3}{*}{ Pengalam } & X1.1 & 0.900 & Valid \\
an & X1.2 & 0.828 & Valid \\
& X1.3 & 0.880 & Valid \\
& X1.4 & 0.922 & Valid \\
Xeterampi & X2.1 & 0.843 & Valid \\
lan & X2.3 & 0.805 & Valid \\
& X2.4 & 0.848 & Valid \\
& X2.5 & 0.866 & Valid \\
Networkin & X3.1 & 0.723 & Valid \\
$g$ & X3.2 & 0.732 & Valid \\
Motivasi & X3.3 & 0.780 & Valid \\
& Z.1 & 0.737 & Valid \\
& & 0.857 & Valid
\end{tabular}

\begin{tabular}{cccc}
\hline Variabel & Indikator & Load & Ket \\
\hline Usaha & Z.2 & 0.863 & Valid \\
& Z.3 & 0.780 & Valid \\
& Y.1 & 0.855 & Valid \\
Kinerja & Y.2 & 0.868 & Valid \\
UMKM & Y.3 & 0.783 & Valid \\
& Y.4 & 0.782 & Valid \\
& Y.5 & 0.778 & Valid \\
\hline
\end{tabular}

Sumber : Data Hasil Olahan, 2020

\section{Uji Reliabilitas}

Reliabilitas dari suatu pengukuran mengindikasikan stabilitas dan konsistensi dari instrumen yang mengukur suatu konsep dan berguna untuk menguji suatu "kebaikan" dari pengukuran tersebut

Tabel 2: Hasil Uji Cronbach's Alpha Konstruk Variabel Penelitian

\begin{tabular}{lcl}
\hline \multicolumn{1}{c}{ Variabel } & Cronbach's Alpha & Ket \\
\hline Pengalaman & 0,906 & Reliabel \\
Keterampilan & 0,896 & Reliabel \\
Networking & 0,729 & Reliabel \\
Motivasi Usaha & 0,780 & Reliabel \\
Kinerja UMKM & 0,872 & Reliabel \\
\hline
\end{tabular}

Sumber : Data Hasil Olahan, 2020

\section{Koefisien Determinasi}

Koefisien determinasi menggunakan Adjusted $R$-squared yang menunjukkan berapa persentase variasi konstruk endogen/kriterion dapat dijelaskan oleh konstruk yang dihipotesiskan memengaruhinya (eksogen/prediktor). Adjusted $R$-squared hanya ada untuk variabel endogen (Sholihin dan Ratmono, 2013:62).

Hasil nilai Adjusted $R$-squared dapat dilihat sebagai berikut:

Tabel 3: Hasil Uji Koefisien Determinasi

\begin{tabular}{ccc}
\hline Struktur & $\boldsymbol{R}$ Square & $\begin{array}{c}\text { Adjusted } \\
\boldsymbol{R} \text { Square }\end{array}$ \\
\hline Kinerja UMKM & 0,509 & 0,463 \\
\hline $\begin{array}{c}\text { Sumber : Data Hasil Olahan, } 2020 \\
\text { Uji Hipotesis }\end{array}$
\end{tabular}


Dalam hal ini dilakukan metode bootstrapping terhadap sampel, pengujian dengan bootstrapping juga dimaksudkan untuk meminimalkan masalah pada data penelitian. Hasil pengujian dengan bootstrapping dari analisis PLS dapat dilihat sebagai berikut:

Uji PLS atau Partial Least Square merupakan pendekatan persamaan struktrural (Structural Equation Modelling/SEM) berbasis varian. Pendekatan ini digunakan untuk melakukan analisis jalur yang banyak digunakan dalam studi keperilakuan, sehingga PLS menjadi teknik statistik yang digunakan dalam model yang lebih dari satu variabel dependen dan variabel independen

Tabel 4 Hasil Pengujian Hipotesis

\begin{tabular}{|c|c|c|c|}
\hline Pengaruh & Path Coef & $\begin{array}{c}P \\
\text { value }\end{array}$ & Ket \\
\hline $\mathrm{X} 1 \rightarrow \mathrm{Y}$ & 0.329 & 0.002 & $\begin{array}{c}\text { Positif \& } \\
\text { Signifikan }\end{array}$ \\
\hline $\mathrm{X} 2 \rightarrow \mathrm{Y}$ & 0.397 & 0.001 & $\begin{array}{c}\text { Positif \& } \\
\text { Signifikan }\end{array}$ \\
\hline $\mathrm{X} 3 \rightarrow \mathrm{Y}$ & 0.198 & 0.041 & $\begin{array}{c}\text { Positif \& } \\
\text { Signifikan }\end{array}$ \\
\hline $\mathrm{Z}^{*} \mathrm{X} 1 \rightarrow \mathrm{Y}$ & 0.087 & 0.227 & $\begin{array}{l}\text { Positif \& Tidak } \\
\text { Signifikan }\end{array}$ \\
\hline $\mathrm{Z}^{*} \mathrm{X} 2 \rightarrow \mathrm{Y}$ & 0.058 & 0.313 & $\begin{array}{l}\text { Positif \& Tidak } \\
\text { Signifikan }\end{array}$ \\
\hline $\mathrm{Z}^{*} \mathrm{X} 3 \rightarrow \mathrm{Y}$ & 0.202 & 0.038 & $\begin{array}{l}\text { Positif \& } \\
\text { Signifikan }\end{array}$ \\
\hline
\end{tabular}

Sumber : Data Hasil Olahan, 2020

Dari Tabel 4 dapat diketahui hasil pengujian hipotesis sebagai berikut:

1. Pengalaman $\rightarrow$ Kinerja UMKM Diperoleh nilai p-value sebesar 0,002 (dibawah $\alpha: 0,05$ ) dengan nilai koefisien path 0,329 . Artinya adalah bahwa pengalaman berpengaruh positif dan signifikan terhadap kinerja UMKM dengan kata lain adalah hipotesis diterima. Setiap peningkatan pengalaman sebesar 1 satuan maka akan meningkatkan kinerja UMKM sebesar 0,329 dan sebaliknya dengan asumsi variabel lain tetap. Semakin baik Pengalaman maka kinerja UMKM akan meningkat dan sebaliknya, semakin kurang Pengalaman maka kinerja UMKM akan semakin menurun.

2. Keterampilan $\rightarrow$ Kinerja UMKM Diperoleh nilai p-value $<0,001$ (dibawah $\alpha: 0,05$ ) dengan nilai koefisien path 0,397. Artinya adalah bahwa keterampilan berpengaruh positif dan signifikan terhadap kinerja UMKM dengan kata lain adalah hipotesis diterima. Setiap peningkatan keterampilan sebesar 1 satuan maka akan meningkatkan kinerja UMKM sebesar 0,397 dan sebaliknya dengan asumsi variabel lain tetap. Semakin baik Keterampilan maka kinerja UMKM akan meningkat dan sebaliknya, semakin kurang Keterampilan maka kinerja UMKM akan semakin menurun.

3. Networking $\rightarrow$ Kinerja UMKM

Diperoleh nilai p-value sebesar 0,041 (dibawah $\alpha: 0,05$ ) dengan nilai koefisien path 0,198. Artinya adalah bahwa networking berpengaruh positif dan signifikan terhadap kinerja UMKM dengan kata lain adalah hipotesis diterima. Setiap peningkatan networking sebesar 1 satuan maka akan meningkatkan kinerja UMKM sebesar 0,397 dan sebaliknya dengan asumsi variabel lain tetap. Semakin baik Networking maka kinerja UMKM akan meningkat dan sebaliknya, semakin kurang baik Networking maka kinerja UMKM akan semakin menurun.

4. Motivasi Usaha * Pengalaman $\rightarrow$ Kinerja UMKM

Diperoleh nilai p-value sebesar 0,227 (diatas $\alpha: 0,05$ ) dengan nilai koefisien path 0,087. Artinya adalah bahwa pengalaman 
berpengaruh positif namun tidak signifikan terhadap kinerja UMKM dengan motivasi usaha sebagai variabel moderasi dengan kata lain adalah hipotesis ditolak. Setiap peningkatan interaksi motivasi usaha dengan pengalaman sebesar 1 satuan maka akan meningkatkan kinerja usaha sebesar 0,087 dan sebaliknya dengan asumsi variabel lain tetap.

5. Motivasi Usaha * Keterampilan $\rightarrow$ Kinerja UMKM

Diperoleh nilai $p$-value sebesar 0,313 (diatas $\alpha: 0,05$ ) dengan nilai koefisien path 0,058. Artinya adalah bahwa keterampilan berpengaruh positif namun tidak signifikan terhadap kinerja UMKM dengan motivasi usaha sebagai variabel moderasi dengan kata lain adalah hipotesis ditolak. Setiap peningkatan interaksi motivasi usaha dengan keterampilan sebesar 1 satuan maka akan meningkatkan kinerja usaha sebesar 0,058 dan sebaliknya dengan asumsi variabel lain tetap.

6. Motivasi Usaha * Networking $\rightarrow$ Kinerja UMKM

Diperoleh nilai p-value sebesar 0,038 (dibawah $\alpha: 0,05$ ) dengan nilai koefisien path 0,202 . Artinya adalah bahwa networking berpengaruh positif dan signifikan terhadap kinerja UMKM dengan motivasi usaha sebagai variabel moderasi dengan kata lain adalah hipotesis diterima. Setiap peningkatan interaksi motivasi usaha dengan networking sebesar 1 satuan maka akan meningkatkan kinerja usaha sebesar 0,202 dan sebaliknya dengan asumsi variabel lain tetap.

Kesimpulan dan Saran

Kesimpulan
Dari hasil penelitian yang telah dipaparkan sebelumnya, maka dapat ditarik kesimpulan penelitian ini sebagai berikut:

1. Pengalaman berpengaruh terhadap Kinerja UMKM binaan PT Chevron Pacific Indonesia. Semakin baik pengalaman maka Kinerja UMKM akan meningkat dan sebaliknya, semakin kurang baik Pengalaman maka Kinerja UMKM akan semakin menurun.

2. Keterampilan berpengaruh terhadap Kinerja UMKM binaan PT Chevron Pacific Indonesia. Semakin baik Keterampilan maka Kinerja UMKM akan meningkat dan sebaliknya, semakin kurang baik Keterampilan maka Kinerja UMKM akan semakin menurun.

3. Networking berpengaruh terhadap Kinerja UMKM binaan PT Chevron Pacific Indonesia. Semakin baik Networking maka Kinerja UMKM akan meningkat dan sebaliknya, semakin kurang baik Networking maka Kinerja UMKM akan semakin menurun.

4. Pengalaman berpengaruh positif dan tidak signifikan terhadap Kinerja UMKM binaan PT Chevron Pacific Indonesia dengan motivasi usaha sebagai moderasi. baik atau tidaknya pengalaman yang disertai motivasi usaha, tidak memberikan dampak yang signifikan tehadap kinerja UMKM.

5. Keterampilan berpengaruh positif dan tidak signifikan terhadap Kinerja UMKM binaan PT Chevron Pacific Indonesia dengan motivasi usaha sebagai moderasi. bagus atau tidaknya keterampilan yang disertai motivasi usaha, tidak memberikan dampak yang signifikan tehadap kinerja UMKM.

6. Networking berpengaruh terhadap Kinerja UMKM binaan PT Chevron Pacific Indonesia dengan motivasi 
usaha sebagai moderasi. Semakin baik motivasi didalam menambah networking maka Kinerja UMKM akan meningkat dan sebaliknya, semakin kurang baik motivasi maka Kinerja UMKM akan semakin menurun.

Saran

Dari hasil penelitian dan kesimpulan yang sudah dijelaskan sebelumnya, maka penulis memberikan saran sebagai berikut:

1. Diharapkan kepada PT Chevron Pacific Indonesia untuk dapat lebih memperhatikan mengenai cara untuk membentuk dan meningkatkan pengalaman para pelaku UMKM..

2. Meningkatkan kinerja UMKM melalui peningkatan keterampilan yang dilakukan oleh PT Chevron Pacific Indonesia seringkali dianggap hanya sebatas formalitas untuk mendapatkan sertifikat atau piagam. Untuk itu diperlukan adanya evaluasi secara bertahap agar segala pelatihan yang telah diberikan kepada pelaku UMKM teraplikasikan dengan baik pada usahanya masing-masing mulai dari perencanaan keuangan sampai dengan perencanaan pemasaran serta produksi.

3. Didalam membangun Networking hendaknya pihak PT. Chevron Pasifik Indonesia dapat mengayomi serta membimbing para pelaku UMKM agar para UMKM tidak kewalahan didalam memasarkan hasil produksinya. Mengembangkan jaringan usaha dapat dilakukan dengan mengadakan bazar-bazar UMKM atau mengikut sertakan para pelaku UMKM pada event-event yang berskala nasional atau internasional.

4. Diharapkan kepada peneliti selanjutnya untuk menggunakan metode wawancara serta angket terbuka dalam penelitian, agar data yang diperoleh sesuai dengan keadaan yang sebenarnya. Disamping itu juga perlu menambahkan faktor-faktor lain yang mempengaruhi kinerja UMKM berdasarkan karakteristik serta alat analisis yang berbeda.

\section{Daftar Pustaka}

Alma, Buchari. 2014. Pengantar Statistika Sosial. Bandung: Alfabeta

Alhempi, Raden Rudi, \& Harianto, W.

(N.D.). Pengaruh Pelatihan

Dan Pembinaan Terhadap Pengembangan Umkm

Asepta Hendriyanto. Analisis Pengaruh Jaringan Usaha dan Inovasi terhadap Kinerja UMKM. Jurnal Ilmu Manajemen dan Akuntansi Terapan (J'MAT) Vol. 6 No. 1 Mei 2015. ISSN 20863748

Edy, Sutrisno. 2011. Manajemen Sumber Daya Manusia. Penerbit: Jakarta, Kencana.

Foster, Bill. 2001. Pembinaan untuk Peningkatan Kinerja Karyawan. Jakarta: PPM

Ghozali, I. \& Fuad. 2008. Structural Equation Modeling. Semarang: Universitas Diponegoro.

Haerudin, Adam, R. P., \& Adda, W. (2015).

Pengaruh

Keterampilan , Motivasi Dan Bantuan Usaha Terhadap Kinerja Industri Kecil Menengah ( IKM ) Meubel Di Kabupaten Tojo Una-Una.

Hamzah, Djabir, dan Djaya. (2012). "Faktor - Faktor Knowledge Management yang

Berpengaruh Terhadap Kinerja Tenaga Kependidikan Universitas Hasanudin". Universitas Hassanudin 2012. 113

Handoko, T. Hani, 2012. Manajemen Personalia Dan Sumber Daya 
Manusia, Edisi Kedua, BPFE, Yogyakarta

Hair, Jr et.al. (2010). Multivariate Data Analysis (7th ed). United States : Pearson.

Harini, S. (N.D.). Pengaruh Pelatihan Entrepreneurship Dan Manajemen Usaha Terhadap Pendapatan Usaha Mikro Makanan Dan Minuman. 7380.

Hasibuan, Malayu S.P. 2010. Manajemen Sumber Daya Manusia. Jakarta: PT Bumi Aksara

Hariandja, 2012, Manajemen Sumber Daya Manusia, Gramedia Widiasarana, Jakarta

Hendriyanto, A. (2015). Analisis Pengaruh Jaringan Usaha Dan Inovasi Terhadap Kinerja Umkm. Sekolah Tinggi Ilmu Ekonomi Totalwin Semarang. 6, 44-49.

Indarti, N. (2004). Proceeding of the second bi-annual Europe Summer University. Enschede: University of Twente.

Kadarisman, M. 2013. Manajemen Pengembangan Sumber Daya Manusia. Depok: Raja Grafindo Persada

Kandula R. Srinivas. 2013. Competency Based Human Resource Management, Gate Corporation, Bangalore, Delhi.

Latan. 2014. Partial Least Squares : Konsep, Teknik dan Aplikasi Menggunakan Program PLS edisi kedua. Universitas Diponegoro, Semarang.

Lao, S.K, (2007), Measuring Chinese Entrepreneurial Motivation: Personality and Environmental Influences. International Journal of Enterpreneurial Behaviour and Research, 13: 200-221
Mangkunegara. 2015. Sumber Daya Manusia Perusahaan. Cetakan kedua belas. Remaja Rosdakarya:Bandung

Marhanani, F. A. (2017). Implementasi Corporate Social Responsibility (CSR) Dalam Menunjang Kinerja Umkm (Studi Kasus Pada Sentra Industri Kampoeng Batik Laweyan Solo).

Mathis. 2011. Manajemen Sumber Daya Manusia. Buku 1, Alih Bahasa: Jimmy Sadeli dan Bayu. Prawira Hie, Salemba Empat. Jakarta.

Moeheriono. 2012. Pengukuran Kinerja Berbasis Kompetensi. Jakarta: Raja Grafindo Persada.

Mudjiarto, Wahid, A., \& Sugiharto, A. (2016). Faktor- Faktor Yang Mempengaruhi Kinerja Usaha Kecil Menengah (Ukm) Mitra Binaan PKBL PT Jasa Marga.

Munizu (2010). Pengaruh FaktorFaktor dan Internal Terhadap Kinerja Usaha Mikro dan Kecil (UMK) di Sulawesi Selatan. Jurnal Manajemen dan Kewirausahaan, Vol 12, No.1, Maret 2010:33-41

Mulyana, \& Sutapa. (2016). Dampak Collaborative Networks Pada Peningkatan Kinerja Industri Kreatif. 778-785.

Murdiono. (2012)

Strategi

Pembelajaran

Kewarganegaraan Berbasis Portofolio. Yogyakarta: Ombak.

Narisyah, C. L. (2018). Pengaruh Corporate Social Responsibility (Csr) Bank Indonesia Provinsi Aceh Terhadap Program Umkm Untuk Meningkatkan Pemberdayaan Masyarakat.

Nova, (2013). Crisis Public Relatons Bagaimana PR Menangani 
Krisis Perusahaan. Jakarta: Raja Grafindo Persada

Pramudyo, Anung. 2010. Analisis Faktor-Faktor yang Mempengaruhi Kinerja Dosen Negeri Dipekerjakan pada Kopertis Wilayah V Yogyakarta. Vol.1 No.1

Rivai, Veithzal dan Ella Sagala, 2013. Manajemen Sumber Daya Manusia untuk Perusahaan, Rajawali Pers, Jakarta

Robbins, Stephen P. And Coulter, Marry. (2012). Management. New Jersey: Pearson Education, Inc

Sedarmayanti. (2015). Manajemen Sumber Daya Manusia. Bandung: Refika Aditama

Siagian, Siondang. (2010). Manajemen Sumber Daya Manusia, Bumi Aksara, Jakarta.

Sholihin, Mahfud, Ph.D dan Ratmono Dwi, Dr (2013) “ Analisis SEMPLS dengan WrapPLS 3.0 untuk Hubungan Nonlinier dalam Penelitian Sosial dan Bisnis". Penerbit Andi Offset. Yogyakarta.

Sugiyono, (2016), Metode Penelitian Kuantitatif, Kualitatif dan Kombinasi (Mixed Method). Alfabeta, Bandung

Sugiyono. (2017). Metode Penelitian Pendidikan Pendekatan Kuantitatif, Kualitatif, dan R\&D. Bandung: Alfabeta

Sugiyono. (2018). Metode Penelitian Kuantitatif, Kualitatif dan R\&D. Bandung: Alfabeta

T. Hani, Handoko. 2011. Manajemen, Edisi Kedua. Yogyakarta: BPFE Yogyakarta

Trijoko. (2008). Ilmu Budaya Dasar. Jakarta: PT Rineka Cipta.

Veithzal Rivai dan Basri. 2016. Performance Appraisal: Sistem Yang Tepat Untuk Menilai Kinerja Karyawan Dan
Meningkatkan Daya Saing Perusahaan. Grafindo. Jakarta.

Winardi, J. 2016. Motivasi dan Pemotivasian

Dalam Manajemen. Jakarta: Raja Grafindo Persada. 